\title{
CHEMICAL CONTROL OF FOLIAR DISEASES IN SOYBEAN DEPENDS ON CULTIVAR AND SOWING DATE
}

\author{
O CONTROLE QUÍMICO DE DOENÇAS FOLIARES NA CULTURA DA SOJA \\ DEPENDE DO CULTIVAR E DA ÉPOCA DE PLANTIO
}

\author{
Rodrigo DE ALMEIDA ${ }^{1}$; Carlos Alberto FORCELINI ${ }^{1}$; Felipe Rafael GARCÉS-FIALLOS ${ }^{2}$ \\ 1 Agronomist Engineer, MSc Agronomy (Plant Pathology), University of Passo Fundo. Passo Fundo, RS, Brazil. 2 Agronomist Engineer, Specialist \\ in Microbiology, MSc Plant Pathology, PhD Plant Pathology. Professor at Faculty of Agronomy and Veterinary Medicine, University of Passo \\ Fundo. Passo Fundo, RS, Brazil. 3 Agronomist Engineer, MSc Agronomy (Plant Pathology), PhD Plant Genetic Resources. Professor at Faculty of \\ Industrial Engineers, University of Guayaquil. Guayaquil, Ecuador. Email: felipe.garcesf@ug.edu.ec
}

\begin{abstract}
The aim was to study the effect of early application of two fungicide mixtures on the control of Asian rust and powdery mildew, as well as on grain yield in five soybean cultivars at two sowing dates. The experiment was carried in the experimental area of FAMV/UPF. The cultivars A 4910 RG (super-early), BMX Apolo RR, A 6001 RR and Fundacep 55 RR (early) and Coodetec 214 RR (moderate), established at 13/11/2007 and 3/12/2007 were used. Trifolia of these cultivars were treated twice with the fungicides ciproconazol + azoxystrobin (Priori Xtra ${ }^{\circledR}, 0.3 \mathrm{~L}$ ha- 1 plus Nimbus ${ }^{\circledR}$ adjuvant 0.6 L ha ${ }^{1}$ ) and epoxiconazol + pyraclostrobin $\left(\right.$ Opera $\left.{ }^{\circledR}, 0.5 \mathrm{~L} \mathrm{ha}^{-1}\right)$, in three moments 1: pre-closure of the space between the lines and 21 days after; 2: pre-closure of space between rows and R5.1 stage (10\% of beginning seed); and 3: R1 (beginning bloom) and R5.1 stages. The severity (\% of affected leaf area) of powdery mildew and number of lesions $\mathrm{cm}^{2}$ of Asian rust were evaluated. After that plants were harvested, the thousand grain weight $(\mathrm{g})$ and grain yield $\left(\mathrm{kg} \mathrm{ha}^{-1}\right)$ were quantified. The experimental design was a split-plot with four replicates, where the main plot were the five cultivars, and the subplots were the control treatment (untreated plants) and the six chemical control programs. Tukey and t-Student tests ( $\leq 0.05$ ) were used for separation of means of treatments and seasons, respectively. In general terms, foliar application of fungicides controlled both Asian rust and powdery mildew, as well as generated an increase on the thousand grain weight and grain yield. However, there seems to be an interaction among soybean genotypes and sowing date. Thus, our results allow us to infer that the chemical control of leaf diseases in the soybean crop depends of the cultivar and sowing date.
\end{abstract}

KEYWORDS: Glycine max L. Triazols. Strobilurins. Powdery mildew. Asian soybean rust. Grain yield.

\section{INTRODUCTION}

Diseases are the major problem in soybean crop, causing great damage and losses annually. In Southern Brazil, Asian rust (Phakopsora pachyrhizi Syd. \& P. Syd.) and powdery mildew (Erysiphe diffusa (Cooke \& Peck) U. Braun \& S. Takam.) stand out. Asian rust intensity is directly influenced by the frequency of rainfall over the crop cycle (DEL PONTE et al., 2006). However, powdery mildew has been more intense in this region of the country in recent seasons due to low rainfall (DE ALMEIDA et al., 2014). In susceptible cultivars, both Asian Rust and powdery mildew may originate yield losses between 35 and 90\%, respectively (HARTMAN et al., 1999).

The current soybean cultivars are susceptible to these foliar diseases, but there are variations in intensity among genotypes, due to possibly the climatic conditions of each season. These predisposing conditions in the no-tillage crop environment are related to the sowing time, due to the temperature and wetting conditions of each period (DE ALMEIDA et al., 2014).

The use of synthetic fungicides is the main tool used currently for the control foliar diseases, thus preserving the productive potential of soybean crop. However, some factors such as genotype choice, timing of application and season may affect the fungicides efficiency. For example, applications still in vegetative stages of crop and repeated up to three times, besides controlling the Asian rust, can generate an increase of plants leaf area, unlike of later applications (BOLLER et al., 2008; GARCÉSFIALLOS; FORCELINI, 2011a; 2011b). For the control of powdery mildew in early cultivars with lower leaf area index, applications may be done before (BOLLER et al., 2008). On the other hand, the use of early-cycle cultivars and sowing at preferential times, but not late, may prevent a longer exposure time of trifolia to pathogen (REIS et al., 2006). However, the management of diseases such as Asian rust, as well as the choice of application time, is important in the maintenance of soybean leaves, 
which finally reflect in a higher grain weight (GARCÉS-FIALLOS; FORCELINI; 2011b).

Recommendations about fungicides spraying still in vegetative stage of soybean (pre-closure of space between the sowing lines), may reach the middle and lower third of plants, resulting in an adequate management of main diseases and increases in yield, stimulated the conduct of this experiment. Thus, the aim was to study the effect of early application of two fungicide mixtures on the control of Asian rust and powdery mildew, as well as on grain yield in five soybean cultivars at two sowing dates.

\section{MATERIAL AND METHODS}

The experiment was carried in the experimental area of Faculty of Agronomy and Veterinary Medicine, University of Passo Fundo, at $2007 / 08$ crop season. Seed soybeans were sown in two seasons, the first at 13/11/2007 and the second at 03/12/2007.

\section{Genotypes and treatments}

Five cultivars of different cycles (DE ALMEIDA et al., 2014) were used, being three superearly (A 4910 RG), early (BMX Apolo RR, A 6001 RR and Fundacep 55 RR) and moderate (Coodetec 214 RR). The genotypes were chosen because they represent a large area of cultivation in State of Rio Grande do Sul.

Trifolia of the five cultivars were treated twice with the fungicides ciproconazol + azoxystrobin (Priori Xtra $^{\circledR}, 0.3 \mathrm{~L} \mathrm{ha}^{-1}$ plus Nimbus ${ }^{\circledR}$ adjuvant $0.6 \mathrm{~L}$ $\left.\mathrm{ha}^{-1}\right)$ and epoxiconazol + pyraclostrobin $\left(\right.$ Opera ${ }^{\circledR}, 0.5$ $\left.\mathrm{L} \mathrm{ha}^{-1}\right)$, in three moments 1: pre-closure of the space between the lines and 21 days after; 2: pre-closure of space between rows and R5.1 stage (10\% of beginning seed); and 3: R1 (beginning bloom) and R5.1 stages. The volume of broth used in all applications was $200 \mathrm{~L} \mathrm{ha}^{-1}$, with spray tip TJ60 11002 (100), using a $\mathrm{CO}^{2}$ pressurized spray, calibrated at a pressure of 2 bar.

\section{Experimental conditions}

The area used in this experiment contained white oats as previous crop (crop established during the winter harvest). With a no-tillage seeder were sown 12 seeds per linear meter. These seeds were first treated with the insecticide imidacloprid + thiodicarb $\left(\right.$ Cropstar $\left.^{\circledR}, 0.3 \mathrm{~L} \mathrm{ha}^{-1}\right)$ and the fungicide carbendazin + thiram (Derosal Plus ${ }^{\circledR}, 0.2 \mathrm{~L} \mathrm{ha}^{-1}$ ). The experimental units were had six rows of five $\mathrm{m}$ spaced by $0.45 \mathrm{~m}$, totaling $11.25 \mathrm{~m}^{2}$ and 360 plants per experimental unit. The four rows central were considered the useful plot.

Fertilization in the sowing line was arranged of $250 \mathrm{~kg} \mathrm{ha}{ }^{-1}$ of formula $\mathrm{N}-\mathrm{P}_{2} \mathrm{O}_{5}-\mathrm{K}_{2} \mathrm{O}(0-20-30)$. Three applications of insecticides were carried during crop growth cycle. Other activities related to experiment management were carried out according to culture needs.

\section{Evaluation of powdery mildew and Asian rust}

The severity (\% of affected leaf area) of powdery mildew and number of lesions $\mathrm{cm}^{2}$ of Asian rust were quantified in all central leaflets of five soybean plants harvested at random on the two outer lines of the experimental unit. A stereoscopic microscope (ZEISS model Stemi 2000-C) was used for the quantification of these diseases. The severity assessment powdery mildew was estimated at $01 / 13$ and repeated at 01/23, 02/2, 12/02, 22/02, 03/03, $03 / 13$ and $03 / 23$. The integration of the cumulative scores resulted in the area under the disease progress curve (AUDPC), according to trapezoidal integration equation described in Campbell; Madden (1990). The number of lesions $\mathrm{cm}^{2}$ only was quantified at phenological stage R7.1 (beginning maturity and green leaflets).

\section{Quantification of thousand grain weight and grain yield}

Grain was harvested using a Wintersteiger combine harvester (Win-tersteiger AG, Ried/I, Austria), on the four central lines at phenological stage R9 (harvest maturity). Immediately after the harvest, the grains were separated from the impurity, standardized to $13 \%$ humidity and estimated the thousand grain weight $(\mathrm{g})$ and grain yield $\left(\mathrm{kg} \mathrm{ha}^{-1}\right)$. Plots of Fundacep 55 RR and CD 214RR plants established in the second season were affected by hail rain at 21/04/2008.

\section{Experimental design and statistical analysis}

The experimental design was a split-plot with four replicates, where the main plot were the five cultivars, and the subplots were the control treatment (untreated plants) and the six chemical control programs. After verification of homogeneity of the variances (Bartlett's test) and normality of the residues (Shapiro-Wilks test), data were subjected to analysis of variance. When the assumptions were satisfied, the 
data were submitted to ANOVA. Tukey and t-Student tests $(\mathrm{p} \leq 0.05)$ were used for separation of means of treatments and sowing date, respectively. All the analysis was performed in the GraphPad $^{\circledR}$ Prism 5 statistical software.

\section{RESULTS AND DISCUSSION}

\section{Evaluation of powdery mildew and Asian rust}

Although Asian rust and powdery mildew were found and evaluated, the second disease affected the soybean cultivars more intensively over time.
Perhaps the climatic conditions favored only powdery mildew. The average temperature and total rainfall among 01/01 and 04/04/2008 were $20.2{ }^{\circ} \mathrm{C}$ and 660.3 $\mathrm{mm}$, respectively. Precipitation was below normal in January (Figure 1). Erysiphe diffusa the causal agent of powdery mildew, is favored by temperatures between 18 and $24{ }^{\circ} \mathrm{C}$, and does not need leaf wetting, requiring only of between 50 and $90 \%$ relative air humidity (HARTMAN et al., 1999; GONÇALVES et al., 2009), conditions that were recorded in the experiment.

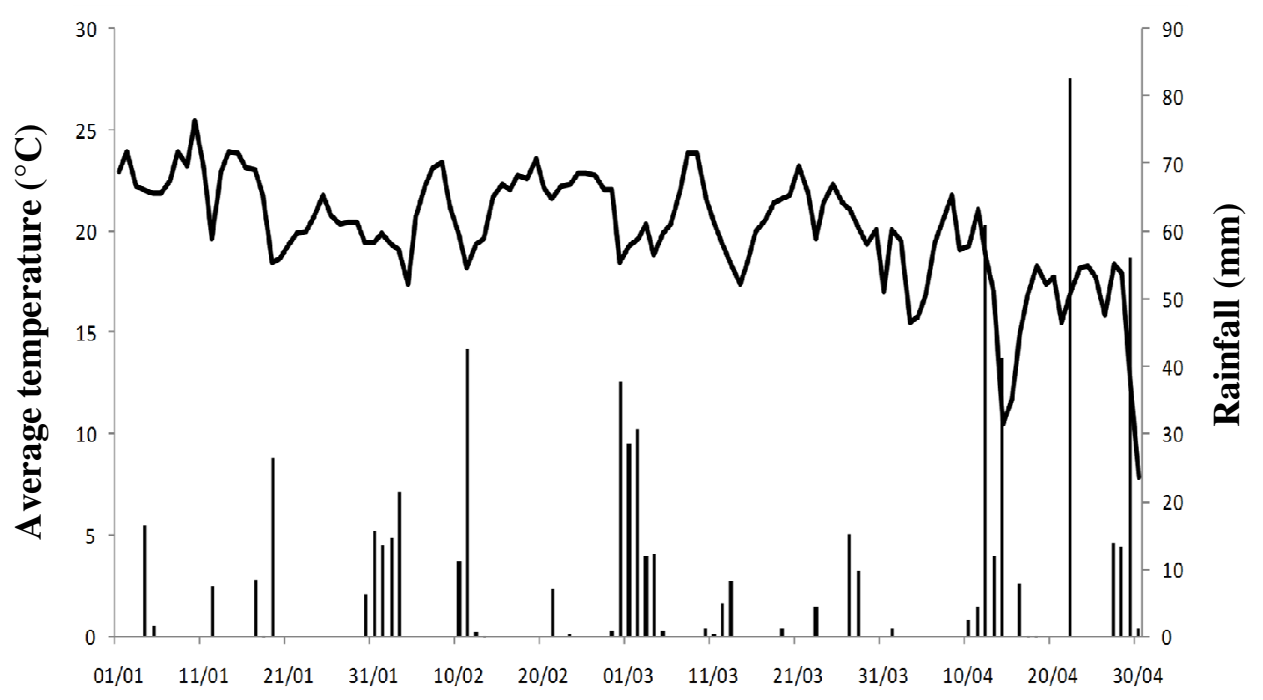

Figure 1. Rainfall (columns, mm) and average daily temperature (line, ${ }^{\circ} \mathrm{C}$ ) from 01/01/2008 to 04/30/2008 in Passo Fundo, RS. Source: www.cnpt.embrapa/agromet/

The mixtures of fungicides applied at the three times reduced the AACPD of powdery mildew in average $50 \%$, in most cultivars in the two sowing date, when compared to control (Table 1). The exception was in cv. Fundacep 55 RR in the second season, where the average spraying of pyraclostrobin + epoxiconazol at pre-closure of space between rows and phenological stage R5.1 was similar to control. It is known that mixtures as strobirulins and triazols efficiently controls the powdery mildew (GODOY; CANTERI, 2004). On the other hand, the advantage of use of fungicides mixtures is that the possibility of selection of fungicide resistant strains of powdery mildew may be reduced, besides contributing to the control of other soybean diseases as Asian rust (BLUM et al., 2002).
The AACPD of powdery mildew was different among the treatments with fungicide in some cultivars (Table 1). For instance, a higher control of powdery mildew was observed in leaflets of cv. BMX Apolo RR sprayed with azoxystrobin + ciproconazol in the second season. Although the two mixtures have similar chemical groups, there is the possibility that one of them has higher efficiency. In this regard, Garcés-Fiallos et al. (2011) comparing the efficiency of two fungicide mixtures to control leaf diseases in wheat crop, they found that pyraclostrobin + epoxiconazol together with spray nozzles that generate fine drops, besides controlling the diseases may generate an increase in grain yield. Another possibility is that the leaf area of some genotypes interfered in the fungicides spraying. 
Table 1. Area under the disease progress curve (AUDPC) of powdery mildew based on the severity (\%) on leaflets of six genotypes established in two sowing date, treated twice with the fungicides ciproconazol + azoxystrobin and epoxiconazol + pyraclostrobin, in three moments 1: pre-closure of the space between the lines and 21 days after; 2: pre-closure of space between rows and R5.1 stage (10\% of beginning seed); and 3: R1 (beginning bloom) and R5.1 stages. Passo Fundo, RS, Brasil. Harvest 2007-2008

\begin{tabular}{|c|c|c|c|c|c|c|c|c|c|c|c|}
\hline \multirow{3}{*}{ Fungicide } & \multirow{3}{*}{ Stage } & \multicolumn{10}{|c|}{ GENOTYPES } \\
\hline & & \multicolumn{2}{|c|}{ A 4910 RG } & \multicolumn{2}{|c|}{ BMX Apolo RR } & \multicolumn{2}{|c|}{ A 6001 RR } & \multicolumn{2}{|c|}{ Fundacep 55 RR } & \multicolumn{2}{|c|}{ Coodetec 214 RR } \\
\hline & & I & II & I & II & I & II & $\mathbf{I}$ & II & I & II \\
\hline \multicolumn{2}{|c|}{ Untreated plants } & $65.11 \mathrm{a}$ & $96.57 \mathrm{a}$ & $68.23 \mathrm{a}$ & $125.39 \mathrm{a}$ & $69.67 \mathrm{a}$ & $115.01 \mathrm{a}$ & $37.98 \mathrm{a}$ & $71.17 \mathrm{a}$ & $40.63 a$ & $121.81 \mathrm{a}$ \\
\hline \multirow{3}{*}{$\begin{array}{c}\text { Azoxystrobin } \\
+ \\
\text { Ciproconazol }\end{array}$} & PRE + 21 days & $10.55 b^{1}$ & $27.48 \mathrm{c}$ & $14.75 b$ & $58.00 \mathrm{c}$ & $28.76 b$ & $48.35 b$ & $5.23 b$ & $26.59 c$ & $13.19 b$ & $71,56 \mathrm{c}$ \\
\hline & PRE + R5.1 & $15.57 b$ & $22.16 \mathrm{c}$ & $21.31 b$ & $55.14 \mathrm{c}$ & $37.05 b$ & $51.31 b$ & $11.33 b$ & $22.39 \mathrm{c}$ & $22.68 b$ & $75,45 c$ \\
\hline & R1 + R5.1 & $22.59 \mathrm{~b}$ & $53.17 \mathrm{~b}$ & $20.85 b$ & $52.48 \mathrm{c}$ & $24.01 \mathrm{~b}$ & $54.82 \mathrm{~b}$ & $8.00 \mathrm{~b}$ & $31.41 \mathrm{bc}$ & $15.14 b$ & $66,67 \mathrm{c}$ \\
\hline \multirow{3}{*}{$\begin{array}{c}\text { Pyraclostrobin + } \\
\text { Epoxiconazol }\end{array}$} & PRE + 21 days & $24.70 b$ & $54.35 b$ & $26.87 b$ & $99.70 b$ & $32.78 b$ & $69.42 b$ & $10.68 b$ & $25.93 c$ & $10.97 b$ & $68,92 c$ \\
\hline & PRE + R5.1 & $31.39 b$ & $55.68 \mathrm{~b}$ & $23.90 \mathrm{~b}$ & $90.69 b$ & $33.06 \mathrm{~b}$ & $73.06 \mathrm{~b}$ & $14.49 b$ & $58.67 \mathrm{ab}$ & $25.89 b$ & $100,25 b$ \\
\hline & R1 + R5.1 & $23.77 b$ & $61.94 b$ & $19.74 b$ & $86.57 b$ & $22.86 b$ & $74.09 \mathrm{~b}$ & $13.03 b$ & $32.06 \mathrm{bc}$ & $22.41 b$ & $76,54 \mathrm{c}$ \\
\hline \multicolumn{2}{|c|}{ Means } & $26.98 \mathrm{~B}$ & $53.63 \mathrm{~A}$ & $27.50 \mathrm{~B}$ & 80.79A & $35.20 \mathrm{~B}$ & $68.59 \mathrm{~A}$ & $13.86 \mathrm{~B}$ & $37.91 \mathrm{~A}$ & $21.81 \mathrm{~B}$ & $82.77 \mathrm{~A}$ \\
\hline \multicolumn{2}{|c|}{$\mathrm{CV}(\%)$} & 36.09 & 21.91 & 37.97 & 10.04 & 21.00 & 13.5 & 43.11 & 26.69 & 24.72 & 7.65 \\
\hline
\end{tabular}


Fungicides generated a control of Asian rust in average $80 \%$, when compared to control (Table 2). The efficiency of these mixtures to control this disease has been reported by several authors (GODOY; CANTERI, 2004; SCHERM et al., 2009). For instance, pyraclostrobin + epoxiconazol applied at phenological stage V9 (stem with nine leaf) besides controlling the disease (GARCÉS-FIALLOS; FORCELINI, 2011a; GARCÉS-FIALLOS; FORCELINI, 2013), may generate an increase in leaf area of soybean plants (GARCÉS-FIALLOS; FORCELINI, 2011b). However, the number of lesions $\mathrm{cm}^{-2}$ in control leaflets of some cultivars was similar to treated ones (BMX Apolo RR and Coodetec 214 $\mathrm{RR}$ in the two and the first season, respectively) or some application time (phenological stages R1 and R5.1) with pyraclostrobin + epoxiconazol (A 6001 RR). Perhaps, the low intensity of the disease in these cultivars and sowing date interfered in the results, generating even a high coefficient of variation.

A higher intensity of Asian rust and powdery mildew was observed in the cultivars evaluated in the second sowing season, when compared to first (Tables 1 and 2), possibly due to inoculum source of plants established in the first season. Considering the availability of inoculum, the first crops may present lower disease intensity compared to the later ones. The inoculum availability is higher in areas sown at end of the recommended period (REIS et al., 2006).

Leaf spraying made in the second season at pre-closure of space between rows + phenological stage R5.1 (cvs. Fundacep 55 RR and Coodetec in the two season) and at phenological stages R1 + R5.1 (cv. A 6001 RR) did not efficiently control powdery mildew and Asian rust, respectively. Perhaps, to powdery mildew the time interval was too long, whereas to Asian rust the fungicides application was late.

Between the intensity of diseases and the cycle of cultivars, only was observed an increasing behavior of Asian rust. For instance, the number of lesions $\mathrm{cm}^{-2}$ in leaflets of cv. 4910 RG super-early was in average 20 -fould higher than that of cv. CD 214 RR moderate-cycle (Table 2). The use of earlycycle plants may reduce the time of exposure to pathogen, as well as sowing at preferential seasons, avoiding late sowings. Early-cycle cultivars may have lower damage when compared to late-cycle ones (REIS et al., 2006). According to Forcelini (2009), two applications would be enough to protect the early and semi-early cultivars. However, our results showed that two applications were sufficient to control the disease. What must be taken into account is that in longer-cycle genotypes, there is a final period of one to two weeks in which plants may be damaged by increased disease intensity (FORCELINI, 2009).

\section{Quantification of thousand grain weight and grain yield}

The thousand grain weight was in average $10 \%$ higher in plants treated with fungicide, compared to those not treated (Table 3). Fungicides applications in soybean crops generate a higher number of grains, pods, grains per pods and grain weight per plant (SOARES et al., 2004; GARCÉS-FIALLOS; FORCELINI, 2011b). However, the mixtures and the application times differentially affected this productive variable in the evaluated genotypes.

Although the fungicides applied in pre-closure of the space between the lines may induce an increase of grain yield, besides controlling diseases such as Asian rust (GARCÉS-FIALLOS; FORCELINI, 2013), this behavior seems to depend of genotype and season. For instance, the cvs. A 4910 RG and Fundacep $55 \mathrm{RR}$ in the first and second sowing date, respectively, the thousand grain weight of one of the treatments was similar to control.

Fungicides positively affected grain yield of cv. BMX Apolo RR and A 6001 RR in both sowing date, and of cvs. Coodetec 214 RR and A 4910 RG in the first and second sowing date, respectively, when compared to control (Table 4). Fungicides application in aerial part of soybean crop, besides reducing the Asian rust, may influence in a higher yield of grains (MILES; LEVY, 2007). The higher production obtained in these cultivars was possibly due to protection of healthy leaf area. This variable may influence the grain filling (GARCÉS-FIALLOS; FORCELINI, 2011b), reflecting itself at the end on grain yield. However, this productive variable was influenced by the moment of application, differently in each genotype and season. For example, in the first season the grain yield in cv. A $6001 \mathrm{RR}$ treated with azoxystrobin + ciproconazol was lower than those treated with pyraclostrobin + epoxiconazol. Meanwhile, in the second season there was no difference between fungicides and grain yield.

No difference was found among treatments in cvs. Fundacep 55 RR and Coodetec 214 RR, in the second sowing season. Perhaps, the occurrence of hail rain occurred at 04/21/2008 affected this variable. 
Table 2. Number of lesions $\mathrm{cm}^{2}$ of Asian rust on leaflets of six genotypes established in two sowing date, treated twice with the fungicides ciproconazol + azoxystrobin and epoxiconazol + pyraclostrobin, in three moments 1: pre-closure of the space between the lines and 21 days after; 2 : pre-closure of space between rows and R5.1 stage (10\% of beginning seed); and 3: R1 (beginning bloom) and R5.1 stages. Passo Fundo, RS, Brasil. Harvest 2007-2008

\begin{tabular}{|c|c|c|c|c|c|c|c|c|c|c|c|}
\hline \multirow{3}{*}{ Fungicide } & \multirow{3}{*}{ Stage } & \multicolumn{10}{|c|}{ GENOTYPES } \\
\hline & & \multicolumn{2}{|c|}{ A 4910 RG } & \multicolumn{2}{|c|}{ BMX Apolo RR } & \multicolumn{2}{|c|}{ A 6001 RR } & \multicolumn{2}{|c|}{ Fundacep 55 RR } & \multicolumn{2}{|c|}{ Coodetec 214 RR } \\
\hline & & $\mathbf{I}$ & II & $\mathbf{I}$ & II & $\mathbf{I}$ & II & $\mathbf{I}$ & II & $\mathbf{I}$ & II \\
\hline \multicolumn{2}{|c|}{ Untreated plants } & $1.23 \mathrm{a}$ & $2.19 \mathrm{a}$ & $0.02 \mathrm{a}$ & $1.71 \mathrm{a}$ & $2.84 \mathrm{a}$ & $19.21 \mathrm{a}$ & $13.61 \mathrm{a}$ & $72.98 \mathrm{a}$ & $2.19 \mathrm{a}$ & $58.43 \mathrm{a}$ \\
\hline \multirow{3}{*}{$\begin{array}{c}\text { Azoxystrobin } \\
+ \\
\text { Ciproconazol }\end{array}$} & PRE + 21 days & $0.06 b$ & $0.00 \mathrm{~b}$ & $0.03 \mathrm{a}$ & $0.15 \mathrm{a}$ & $0.66 b$ & $2.76 \mathrm{c}$ & $0.07 b$ & $2.97 \mathrm{~b}$ & $0.42 \mathrm{a}$ & $8,33 b$ \\
\hline & PRE + R5.1 & $0.06 b$ & $0.00 \mathrm{~b}$ & $0.04 \mathrm{a}$ & $0.02 \mathrm{a}$ & $0.05 b$ & $2.48 \mathrm{c}$ & $0.02 \mathrm{~b}$ & $0.68 b$ & $0.51 \mathrm{a}$ & $5,25 b$ \\
\hline & R1 + R5.1 & $0.00 \mathrm{~b}$ & $0.00 \mathrm{~b}$ & $0.02 \mathrm{a}$ & $0.03 \mathrm{a}$ & $0.02 b$ & $3.37 \mathrm{c}$ & $0.06 \mathrm{~b}$ & $0.67 \mathrm{~b}$ & $0.03 \mathrm{a}$ & $3,71 \mathrm{~b}$ \\
\hline \multirow{3}{*}{$\begin{array}{c}\text { Pyraclostrobin + } \\
\text { Epoxiconazol }\end{array}$} & PRE + 21 days & $0.06 \mathrm{~b}$ & $0.19 b$ & $0.03 \mathrm{a}$ & $0.36 \mathrm{a}$ & $0.28 b$ & $8.89 b$ & $1.10 \mathrm{~b}$ & $5.34 b$ & $0.26 \mathrm{a}$ & $6,35 b$ \\
\hline & PRE + R5.1 & $0.18 b$ & $0.02 b$ & $0.03 \mathrm{a}$ & $0.62 \mathrm{a}$ & $0.29 b$ & $8.32 b$ & $0.10 \mathrm{~b}$ & $8.84 \mathrm{~b}$ & $1.39 \mathrm{a}$ & $10,45 b$ \\
\hline & $\mathbf{R 1}+\mathbf{R 5 . 1}$ & $0.18 b$ & $0.29 b$ & $0.03 \mathrm{a}$ & $0.03 \mathrm{a}$ & $0.08 b$ & $17.53 \mathrm{a}$ & $0.38 \mathrm{~b}$ & $3.85 \mathrm{~b}$ & $0.05 \mathrm{a}$ & $5,91 \mathrm{~b}$ \\
\hline \multicolumn{2}{|c|}{ Means } & 0.24 & 0.37 & $0.03 \mathrm{~B}$ & $0.40 \mathrm{~A}$ & $0.57 \mathrm{~B}$ & $8.77 \mathrm{~A}$ & $2.02 \mathrm{~B}$ & $14.12 \mathrm{~A}$ & $0.71 \mathrm{~B}$ & $13.67 \mathrm{~A}$ \\
\hline \multicolumn{2}{|c|}{ CV $(\%)$} & 20.02 & 64.22 & 18.02 & 53.24 & 35.44 & 35.70 & 49.86 & 49.07 & 49.55 & 18.46 \\
\hline
\end{tabular}

${ }^{1}$ Means followed by lowercase and capital letters in the column and row, respectively, do not differ significantly by the Tukey test (p $\leq 0.05$ ). 
Table 3. Thousand grain weight $(\mathrm{g})$ on plants of six genotypes established in two sowing date, treated twice with the fungicides ciproconazol + azoxystrobin and epoxiconazol + pyraclostrobin, in three moments 1: pre-closure of the space between the lines and 21 days after; 2: pre-closure of space between rows and R5.1 stage (10\% of beginning seed); and 3: R1 (beginning bloom) and R5.1 stages. Passo Fundo, RS, Brasil. Harvest 2007-2008

\begin{tabular}{|c|c|c|c|c|c|c|c|c|c|c|c|}
\hline \multirow{3}{*}{ Fungicide } & \multirow{3}{*}{ Stage } & \multicolumn{10}{|c|}{ GENOTYPES } \\
\hline & & \multicolumn{2}{|c|}{ A 4910 RG } & \multicolumn{2}{|c|}{ BMX Apolo RR } & \multicolumn{2}{|c|}{ A $6001 \mathrm{RR}$} & \multicolumn{2}{|c|}{ Fundacep 55 RR } & \multicolumn{2}{|c|}{ Coodetec 214 RR } \\
\hline & & $\mathbf{I}$ & II & $\mathbf{I}$ & II & $\mathbf{I}$ & II & $\mathbf{I}$ & II & $\mathbf{I}$ & II \\
\hline \multicolumn{2}{|c|}{ Untreated plants } & $168.30 \mathrm{c}^{1}$ & $146.66 \mathrm{c}$ & $157.68 \mathrm{c}$ & $128.25 \mathrm{c}$ & $134.35 \mathrm{c}$ & $112.79 \mathrm{c}$ & $155.18 \mathrm{c}$ & $146.89 \mathrm{bc}$ & $119.81 \mathrm{~b}$ & $99.20 \mathrm{~b}$ \\
\hline \multirow{3}{*}{$\begin{array}{c}\text { Azoxystrobin } \\
+ \\
\text { Ciproconazol }\end{array}$} & PRE + 21 days & $188.05 b$ & $164.63 a$ & $166.29 b$ & $146.82 \mathrm{a}$ & $143.71 b$ & $132.36 \mathrm{a}$ & $168.64 b$ & $151.16 \mathrm{ab}$ & $129.45 \mathrm{a}$ & $115,82 \mathrm{a}$ \\
\hline & PRE + R5.1 & $185.24 b$ & $165.41 \mathrm{a}$ & $171.39 \mathrm{a}$ & $146.19 \mathrm{a}$ & $141.35 b$ & $128.61 \mathrm{a}$ & $174.15 a$ & $161.39 a$ & $133.85 \mathrm{a}$ & $116,19 a$ \\
\hline & $\mathbf{R 1}+\mathbf{R 5 . 1}$ & $196.63 a$ & $160.01 \mathrm{a}$ & $179.78 \mathrm{a}$ & $145.34 \mathrm{a}$ & $146.03 b$ & $131.30 \mathrm{a}$ & $174.03 \mathrm{a}$ & $151.24 \mathrm{ab}$ & $137.43 \mathrm{a}$ & $114,84 \mathrm{a}$ \\
\hline \multirow{3}{*}{$\begin{array}{l}\text { Pyraclostrobin + } \\
\text { Epoxiconazol }\end{array}$} & PRE + 21 days & $172.97 \mathrm{c}$ & $160.73 a$ & $168.09 b$ & $136.72 b$ & $146.69 b$ & $120.41 b$ & $168.99 b$ & $148.89 b$ & $138.64 \mathrm{a}$ & $109,98 \mathrm{a}$ \\
\hline & PRE + R5.1 & $189.78 b$ & $161.71 \mathrm{a}$ & $168.24 b$ & $134.36 b$ & $161.87 \mathrm{a}$ & $128.80 \mathrm{a}$ & $161.69 b$ & $140.08 \mathrm{c}$ & $132.05 \mathrm{a}$ & $109,38 \mathrm{a}$ \\
\hline & $\mathbf{R} 1+\mathbf{R 5 . 1}$ & $186.60 \mathrm{~b}$ & $157.79 b$ & $175.36 \mathrm{a}$ & $144.20 \mathrm{a}$ & $156.82 \mathrm{a}$ & $124.10 \mathrm{~b}$ & $176.90 \mathrm{a}$ & $146.31 \mathrm{bc}$ & $127.76 \mathrm{a}$ & $113,87 \mathrm{a}$ \\
\hline \multicolumn{2}{|c|}{ Means } & $183.94 \mathrm{~A}$ & $159.56 \mathrm{~B}$ & $169.55 \mathrm{~A}$ & $140.27 \mathrm{~B}$ & $147.26 \mathrm{~A}$ & $125.48 \mathrm{~B}$ & $168.51 \mathrm{~A}$ & 149.42B & $131.28 \mathrm{~A}$ & $111.87 \mathrm{~B}$ \\
\hline \multicolumn{2}{|c|}{$\mathrm{CV}(\%)$} & 5.14 & 6.31 & 3.32 & 6.85 & 6.29 & 5.94 & 3.84 & 4.18 & 7.45 & 5.62 \\
\hline
\end{tabular}

${ }^{1}$ Means followed by lowercase and capital letters in the column and row, respectively, do not differ significantly by the Tukey test ( $\mathrm{p} \leq 0.05$ ).

Table 4. Grain yield $\left(\mathrm{kg} \mathrm{ha}^{-1}\right)$ on plants of six genotypes established in two sowing date, treated twice with the fungicides ciproconazol + azoxystrobin and epoxiconazol + pyraclostrobin, in three moments 1: pre-closure of the space between the lines and 21 days after; 2: pre-closure of space between rows and R5.1 stage (10\% of beginning seed); and 3: R1 (beginning bloom) and R5.1 stages. Passo Fundo, RS, Brasil. Harvest 2007-2008

\begin{tabular}{|c|c|c|c|c|c|c|c|c|c|c|c|}
\hline \multirow{3}{*}{ Fungicide } & \multirow{3}{*}{ Stage } & \multicolumn{10}{|c|}{ GENOTYPES } \\
\hline & & \multicolumn{2}{|c|}{ A 4910 RG } & \multicolumn{2}{|c|}{ BMX Apolo RR } & \multicolumn{2}{|c|}{ A 6001 RR } & \multicolumn{2}{|c|}{ Fundacep 55 RR } & \multicolumn{2}{|c|}{ Coodetec 214 RR } \\
\hline & & I & II & I & II & I & II & I & II & I & II \\
\hline \multicolumn{2}{|c|}{ Untreated plants } & $3122.43 b^{1}$ & $2309.67 b$ & $2350.80 \mathrm{~b}$ & $2300.40 \mathrm{~b}$ & $2485.78 \mathrm{c}$ & $1561.08 \mathrm{~b}$ & $3595.99 \mathrm{~b}$ & $864.81 \mathrm{a}$ & $2186.79 c$ & $990.62 \mathrm{a}$ \\
\hline \multirow{3}{*}{$\begin{array}{c}\text { Azoxystrobin } \\
+ \\
\text { Ciproconazol }\end{array}$} & PRE + 21 days & $3796.30 \mathrm{a}$ & $3081.27 \mathrm{a}$ & $3994.89 a$ & $3389.51 \mathrm{a}$ & $3499.75 b$ & $2373.44 a$ & $4375.09 a$ & $821.17 \mathrm{a}$ & $2575.16 b$ & $1251,42 \mathrm{a}$ \\
\hline & PRE + R5.1 & $2998.97 b$ & $3266.46 a$ & $4022.42 \mathrm{a}$ & $3402.56 \mathrm{a}$ & $3206.28 b$ & $2191.79 a$ & $4351.98 \mathrm{a}$ & $821.26 \mathrm{a}$ & $2988.89 a$ & $1277,78 \mathrm{a}$ \\
\hline & $\mathbf{R} 1+\mathbf{R 5 . 1}$ & $3261.32 b$ & $3122.43 a$ & $4156.82 \mathrm{a}$ & $3149.16 a$ & $3474.30 \mathrm{~b}$ & $2060.06 \mathrm{a}$ & $4197.64 a$ & $995.53 a$ & $3018.31 \mathrm{a}$ & $1123,73 a$ \\
\hline \multirow{3}{*}{$\begin{array}{c}\text { Pyraclostrobin + } \\
\text { Epoxiconazol }\end{array}$} & PRE + 21 days & $3240.74 b$ & $2937.24 a$ & $4052.01 \mathrm{a}$ & $3044.34 \mathrm{a}$ & $3859.14 a$ & $2128.31 \mathrm{a}$ & $3816.18 \mathrm{ab}$ & $883.39 a$ & $2834.07 \mathrm{a}$ & $1200,92 \mathrm{a}$ \\
\hline & PRE + R5.1 & $3708.85 \mathrm{a}$ & $2906.38 \mathrm{a}$ & $3952.58 \mathrm{a}$ & $3380.09 a$ & $3807.93 a$ & $2183.81 \mathrm{a}$ & $3598.04 b$ & $753.38 \mathrm{a}$ & $2935.54 \mathrm{a}$ & $1117,32 \mathrm{a}$ \\
\hline & $\mathbf{R 1}+\mathbf{R 5 . 1}$ & $3148.15 b$ & $2854.94 \mathrm{a}$ & $3924.57 a$ & $3160.75 a$ & $3734.55 \mathrm{a}$ & $2120.34 \mathrm{a}$ & $4093.36 \mathrm{a}$ & $891.67 \mathrm{a}$ & $2951.45 \mathrm{a}$ & $1306,23 a$ \\
\hline \multicolumn{2}{|c|}{ Means } & $3325.25 \mathrm{~A}$ & $2925.48 B$ & $3779.16 \mathrm{~A}$ & $3118.12 \mathrm{~B}$ & 3409.67A & 2088.40B & $4001.18 \mathrm{~A}$ & 861.60B & $2784.31 \mathrm{~A}$ & $1181.14 \mathrm{~B}$ \\
\hline \multicolumn{2}{|c|}{$\mathrm{CV}(\%)$} & 14.16 & 5.69 & 12.69 & 9.49 & 9.39 & 10.91 & 14.99 & 19.10 & 13.03 & 20.91 \\
\hline
\end{tabular}

${ }^{1}$ Means followed by lowercase and capital letters in the column and row, respectively, do not differ significantly by the Tukey test (p $\leq 0.05$ ). 
A higher thousand grains weight and grain yield was observed in all genotypes planted in the second sowing season, compared to first one. Perhaps, both a higher disease intensity and late sowing may have contributed to reduction of productive potential. The vegetative and productive performance of soybean cultivars are influenced by the sowing date (PEREIRA-PEIXOTO et al., 2000; GALLOTI et al., 2005; GARCÉS-FIALLOS et al., 2014). Even this factor is the one that most influence on grain yield (PEREIRA-PEIXOTO et al., 2000).

In this work was found an interaction among soybean genotypes and planting date in both sanitary and productivity variables. This should be taken into account to recommending the sowing season, as well as fungicides and application times, to control diseases such as Asian rust or powdery mildew.

\section{CONCLUSION}

Our results indicate that the chemical control of leaf diseases in soybean crop depends of the cultivar and sowing date.

RESUMO: O objetivo foi estudar o efeito da aplicação antecipada de duas misturas de fungicidas no controle da ferrugem asiática e do oídio, bem como no rendimento de grãos em cinco cultivares de soja em duas épocas de semeadura. O experimento foi conduzido no campo experimental da FAMV/UPF. Utilizaram-se as cultivares A 4910 RG (super precoce), BMX Apolo RR, A 6001 RR e Fundacep 55 RR (precoces) e Coodetec 214 RR (moderado), estabelecidas em 13/11/2007 e 3/12/2007. Os fungicidas piraclostrobina + epoxiconazole e azoxistrobina + ciproconzole foram pulverizados duas vezes em 1: pré-fechamento do espaço entre as linhas e 21 dias após, 2: pré-fechamento do espaço entre as linhas e R5.1 (10\% de granação), e 3: R1 (início da floração) e R5.1. Avaliaram-se a severidade (\% da área foliar afetada) do oídio e o número de lesões $\mathrm{cm}^{2}$ da ferrugem asiática. Logo após as plantas foram colhidas, o peso de mil grãos (g) e rendimento de grãos $\left(\mathrm{kg} \mathrm{ha}^{-1}\right)$ foram quantificados. $\mathrm{O}$ delineamento experimental utilizado foi o de parcelas divididas com quatro repetições, onde a parcela principal foram as cinco cultivares, e as subparcelas foram o tratamento controle (plantas não tratadas) e os seis programas de controle químico. Para a separação das médias dos tratamentos e épocas, foram utilizados os testes de Tukey e t-Student $(\mathrm{p} \leq 0.05)$, respectivamente. De modo geral, a aplicação foliar de fungicidas controlou tanto a ferrugem asiática como o oídio, assim como também gerou um aumento do peso de mil grãos e rendimento de grãos. No entanto, parece existir uma interação entre os genótipos e data de semeadura. Assim, nossos resultados nos permitem inferir que o controle químico das doenças foliares na cultura da soja depende do cultivar e da data de semeadura.

PALAVRAS-CHAVE: Glycine max L. Triazóis. Estrobilurinas. Oídio. Ferrugem asiática. Rendimento de grãos.

\section{REFERENCES}

BLUM, L. E. B.; REIS, E. M., PRADE, A. G.; TAVELA, V. J. Fungicidas e mistura de fungicidas no controle do oídio da soja. Fitopatologia Brasileira, Brasília, v. 27, n. 2, p. 216-218. 2002.

https://doi.org/10.1590/S0100-41582002000200016

BOLLER, W.; HOFFMANN, L. L.; FORCELINI, C. A.; CASA, R. T. Tecnologia de aplicação de fungicidas parte II. Revisão Anual de Patologia de Plantas, Passo Fundo, v. 16, p. 85-132. 2008.

CAMPBELL, C. L.; MADDEN, L. V. Introduction to Plant Disease Epidemiology. New York: John Wiley \& Sons. Inc. 1990. p. 532.

DE ALMEIDA, R.; GARCÉS-FIALLOS, F. R.; FORCELINI, C. A. Ocorrência e intensidade de doenças foliares e ciclo de cultivo em seis cultivares de soja durante duas épocas de semeadura. Ciencia y Tecnología, Quevedo, v. 7, n. 1, p. 13-21. 2014.

DEL PONTE, E. M.; GODOY, C. V.; LI, X.; YANG, X. B. Predicting severity of Asian soybean rust epidemics with empirical rainfall models. Phytopathology, St. Paul, v. 96, p. 797-803. 2006. 
FORCELINI, C. A. Critérios: preventivo, início da doença e estádio fenológico. In: REIS, E. M. (Org.). Critérios indicadores do momento para a aplicacao de fungicidas visando ao controle de doencas em soja e trigo. Passo Fundo: Aldeia Norte, 2009. p. 46-53.

GARCÉS-FIALLOS, F. R.; FORCELINI, C. A. Control químico de la roya asiática de la soya en el Planalto Medio, RS., Brasil. Agronomía Mesoamericana, Alajuela, v. 22, n. 2, p. 387-395. 2011a.

GARCÉS-FIALLOS, F. R.; FORCELINI, C. A. Progresso temporal da ferrugem e redução sobre a área foliar e os componentes do rendimento de grãos em soja. Acta Agronómica, Palmira, v. 60, n. 2, p. 147-157. 2011 b.

GARCÉS-FIALLOS, F. R.; BOLLER, W.; FERREIRA, M. C.; DURÃO, C. F. Eficiência de fungicidas no controle de doenças foliares na cultura do trigo, em resposta à aplicação com diferentes pontas de pulverização. Scientia Agropecuaria, Trujillo, v. 2, p. 4, p. 229-237. 2011.

GARCÉS-FIALLOS, F. R.; FORCELINI, C. A. Controle comparativo da ferrugem asiática da soja com fungicida triazol ou mistura de triazol + estrobilurina. Bioscience Journal, Uberlândia, v. 29, n. 4, p. 805-815. 2013.

GARCÉS-FIALLOS, F. R.; AMPUÑO-MUÑOZ, S. A.; VÁSCONEZ-MONTÚFAR, G. H. Agronomía, producción y calidad de grano de variedades de soya durante dos épocas de cultivo. Bioscience Journal, Uberlândia, v. 30, n. 2, p. 717-729. 2014.

GALLOTTI, G. J. M.; BALBINOT, J. A. A.; BACKES, R. L. Efeito da época de semeadura e da aplicação de fungicidas no progresso da ferrugem asiática, oídio e doenças de final de ciclo na cultura da soja. Revista de Ciências Agroveterinárias, Lages, v. 4, n. 2, p. 87-93. 2005.

GODOY, C. V.; CANTERI, M. G. Efeito da severidade de oídio e crestamento foliar de cercospora na produtividade da cultura da soja. Fitopatologia Brasileira, Brasília, v. 29, n. 5, p. 526-531. 2004. https://doi.org/10.1590/S0100-41582004000500009

GONÇALVES, E. C. P.; CENTURION, M. A. P. C.; DI MAURO, A. O. Avaliação da reação de genótipos de soja ao oídio em diferentes condições. Summa Phytopathologica, Botucatu, v. 35, n. 2, p. 42-52. 2009.

HARTMAN, G. L.; SINCLAIR, J. B.; RUPE, J. C. Compendium of Soybean Diseases. $4^{\text {th }}$ Ed. Minnesota: APS Press. 1999. p. 100.

MILES, M. R.; LEVY, C.; MOREL, W.; MUELLER, T.; STEINLAGE, T.; VAN RIJ, N.; FREDERICK, R. D.; HARTMAN, G. L. International fungicide efficacy trials for the management of soybean rust. Plant Disease. St. Paul, v. 91, p. 1450-1458. 2007. https://doi.org/10.1094/PDIS-91-11-1450

PEREIRA-PEIXOTO, C.; SOUSA-CÂMARA, G. M. DE; MARTINS, M. C.; SANGLADE-MARCHIORI, L. F.; GUERZONI, R. A.; MATTIAZZI, P. Épocas de semeadura e densidade de plantas de soja: I. Componentes da produção e rendimento de grãos. Scientia Agricola. Piracicaba, v. 57, n. 1, p. 89-96. 2000.

https://doi.org/10.1590/S0103-90162000000100015

REIS, E. M.; REIS, A. C.; CARMONA, M. Doenças da soja I: Ferrugem asiática. Passo Fundo: Universidade de Passo Fundo, 2006. p. 48.

SCHERM, H.; CHRISTIANO, R. S. C.; ESKER, P. D.; DEL PONTE, E. M.; GODOY, C. V. Quantitative review of fungicide efficacy trials for managing soybean rust in Brazil. Crop Protection, Madison, v. 28, n. 9 , p. 774-782. 2009. https://doi.org/10.1016/j.cropro.2009.05.006

SOARES, R. M.; RUBIN, S. A. L.; WIELEWICKI, A. P.; OZELAME, J. G. Fungicidas no controle da ferrugem asiática (Phakopsora pachyrhizi) e produtividade da soja. Ciência Rural, Santa Maria, v. 34, p. 1245-1247. 2004. https://doi.org/10.1590/S0103-84782004000400045 